\title{
The Development of Direct-Contextual Learning:
}

\section{A New Model on Higher Education}

\author{
Agus Budiman ${ }^{1,2}$, Muchlas Samani ${ }^{3}$, Rusijono ${ }^{3}$, Wawan Hery Setyawan ${ }^{4} \&$ Nurdyansyah $^{5}$ \\ ${ }^{1}$ Doctoral Students of Technology Education and Vocational, Universitas Negeri Surabaya, Surabaya, Indonesia \\ ${ }^{2}$ Department of Tarbiyah, Universitas Darussalam Gontor, Ponorogo, Indonesia \\ ${ }^{3}$ Department of Technology Education and Vocational, Universitas Negeri Surabaya, Surabaya, Indonesia \\ ${ }^{4}$ Department of Education, Universitas Islam Kadiri, Kediri, Indonesia \\ ${ }^{5}$ Department of Education, Universitas Muhammadiyah Sidoarjo, Sidoarjo, Indonesia \\ Correspondence: Nurdyansyah, Department of Education, Universitas Muhammadiyah Sidoarjo, Indonesia.
}

Received: August 31, 2020

Accepted: November 16, 2020

Online Published: November 17, 2020

doi:10.5430/ijhe.v10n2p15

URL: https://doi.org/10.5430/ijhe.v10n2p15

\begin{abstract}
The development of Islamic education demands a change in the teaching system that leads to the availability of a constructivist-oriented learning model in constructing Fiqh knowledge more logically and rationally through analyzing the context of people's life. This study aims to develop a Direct-Contextual Learning (DCL) model by integrating the characteristics of direct instruction and contextual learning and improving the learning outcomes of comparative Fiqh in higher education. This type of research included the type of research development (R\&D) with a systematic approach using the Dick and Carey model. The participants involved in this study were 100 first-level undergraduate degrees at Gontor Islamic University who were selected using the purposive sampling technique. The data collection techniques used include questionnaires, literature reviews, and test learning outcomes. This study's results were the DCL model, and the DCL teaching plan that was developed led to better Fiqh learning outcomes. The DCL phases developed to consist of an introduction, presentation, context exploration, confirmation, and closing. This study provides a new learning model at Modern Islamic University that can be used by lecturers to impart student fiqh knowledge without leaving the lecturer's role in facilitating students through critical analysis of the relationship between Fiqh and the context of social life.
\end{abstract}

Keywords: direct instruction, contextual learning, learning model, higher education

\section{Introduction}

The development of Islamic education in the Muslim world encourages changes in the teaching system at the higher education level. Eickelman (1974) stated that these changes were related to contemporary ways of education and Islamic religious knowledge involvement. Eickelman (1978) also explained that the transmission of change could be characterized by a shift in thinking and acting, which leads to the openness of cognitive styles in teaching at the higher education level. According to Rahman (1984), this change is a renewal in Islamic education to avoid Islamic knowledge obtained from various indoctrinations.

Modern Islamic University has recently been required to integrate traditional and modern learning and educational values that come from the importance of Islamic teachings (Yunus, 2018). The Indonesian Ministry of Religious Affairs mentioned that Modern Islamic University needs to adapt to changing times and solve society's problems through Islamic education approaches (Kemenag, 2020). This has inspired Modern Islamic University to produce graduates with the ability to link Islamic religious knowledge with acceptable practices to solve society's problems.

The subject of Fiqh is a subject matter in higher education taught by all Modern Islamic University. This subject has been taught as one of the areas of science in Islamic law that specifically addresses the legal issues that govern various aspects of human life, personal life, community, and human life with God (Noh \& Huda, 2020; Rymarz, 2013). One of the uniqueness of learning Fiqh lies in the determination of learning objectives. The learning objectives of Fiqh for basic level students emphasize the psychomotor aspect, which is measured by the ability to practice worship correctly. Meanwhile, the emphasis on advanced students in higher education is on the cognitive aspects. The cognitive aspect 
is comparative Fiqh, which includes studies of scholars' opinions, similarities, and differences in opinion of the scholars based on acceptable postulates (Zarkasyi, 2015). In general, the learning of Fiqh at Modern Islamic University has emphasized the cognitive aspects. However, the teaching method is still dominated by the memorization-oriented learning model of the scholars' wise words (ulama) and the postulates of the Al-Qur'an and Al-Hadith (Arifin et al., 2019; Tan, 1970).

The learning objectives of Fiqh

A good understanding of Fiqh requires a learning model that emphasizes mastery of concepts constructed based on everyday life. The message of knowing something by understanding can be conveyed well to students (Shavit \& Spengler, 2018; Tan, 1970). Learning that can construct student knowledge from everyday life is contextual learning. The Indonesian Ministry of Religious Affairs mentioned that contextual learning, 1) is a holistic educational process and aims to motivate students to understand the meaning of the subject matter they learned by linking the material to their daily life (personal, social, and cultural context). Therefore, students have flexible knowledge that can be applied (transferred) from a problem to another. 2) It is a learning concept that helps lecturers connect the material they teach and real-world situations by encouraging them to connect the material they teach and their application in their lives as family members and the community. Thus, the meaning of context in contextual learning is to provide meaningful experiences for students in learning, while direct instruction helps lecturers in providing an understanding of Fiqh learning directly to students. Salavera et al. (2019) stated that by giving students broader space in learning through contextual learning, lecturers' role in learning Fiqh in Modern Islamic University should not be overlooked. In the tradition of learning in Modern Islamic University, especially in learning Fiqh, lecturers must be actively involved, especially in guiding students during learning and evaluating appropriate to the purpose of learning Fiqh (Nurtawab, 2019).

Although the Indonesian Ministry of Religious Affairs has indicated that contextual learning is involved in the lowest education level, including the highest, contextual learning in the Fiqh subject at Modern Islamic University did not provide good learning outcomes. The research results by Rymarz (2013) found that students' understanding of Islamic Civilization History was better after receiving direct instruction than contextual learning. Meanwhile, Hassan et al. (2010) the implementation of contextual learning causes students' arguments to be made based on basic personal opinions with little based on postulates from the Al-Qur'an and Al-Hadith. From the results of these previous studies, it can be concluded that although contextual learning has advantages over direct instruction in terms of constructing knowledge by student center learning through a context, negative student learning outcomes in the Fiqh subject are due to the too limited capabilities of the lecturers.

Therefore, direct instruction and contextual learning have similarities to emphasize mastery of students' concepts, but they have different characteristics. Direct instruction is defined as a learning model that emphasizes mastery of concepts and/or behavioral change by prioritizing a deductive approach. In contrast, contextual learning is the conception of teaching and learning that helps lecturers connect subject content to real-world situations (Wang et al. 2020). The context in contextual learning plays a role in helping lecturers link learning materials to real-world situations and motivating students to make connections between knowledge and application in their lives (Amir et al., 2019; Wen \& Katt, 2019). Therefore, integrating the two learning forms a new learning model that will provide a deeper understanding for students, especially in Fiqh subjects in Modern Islamic University. This study uses the integration between direct instruction and contextual learning called the Direct-Contextual Learning (DCL) model. This results in the role of lecturers still being able to freely use direct learning methods, while students still get wider space to find the meaning of learning through contextual learning.

\section{Literature Review}

\subsection{Direct Instruction}

\subsubsection{Definition of Direct Instruction}

Arends (2008) states that direct instruction is a learning model centered on lecturers' role in direct education. Bloom (1971) adds that lecturers must be really able to organize learning presentations because that is the key to the success of direct instruction. The lecturer must be able to proportionally share his time for himself, and for students, the lecturer must be adept at arranging the learning step by step appropriately. According to Rosenshine (1995), to maximize direct instruction, the subject matter must be presented in an active presentation. Lecturers are required to present material that is attractive and as far as possible to involve students, even though the lecturer's direct instruction is the center of learning.

Meanwhile, direct instruction is specifically designed for teaching structured knowledge that is taught in certain steps 
and to help students master procedural knowledge in a variety of complex skills (Arends, 2008). The goal of direct instruction is to build students' declarative skills, conceptual knowledge, and procedural knowledge. Procedural knowledge regarding how to do something, knowledge to be able to link between concepts (Krathwohl \& Anderson, 2010).

\subsubsection{Direct Instruction Characteristics and Syntaxes}

According to Arends (2008), direct instruction does not always have the same name. After quoting the views of several experts by Arends (2008), this model is sometimes called active learning, mastery teaching model, and explicit instruction. Arends (2008) also stated that direct instruction emphasizes how teaching materials are conveyed by lecturers to students so that they can master the maximum even though they are under the names of active learning, mastery teaching model, and explicit instruction.

According to Arends (2008), among the characteristics of direct instruction is the mastery of various procedural skills and factual knowledge that is applied step by step, which is typical. This model is not intended to achieve social learning outcomes or high-level thinking skills. Direct instruction is also known as explicit instruction by Archer \& Hughes (2010).

According to Rosenshine (1995), direct instruction has several characteristics; they are 1). focus on academics; 2). lecturer-centered; 3). few options for students to determine their own activities; 4). used in large classes where there are a large number of students; 5). put forward factual questions, and 6). The lecturer controls the practice of learning. There are six characteristics of direct instruction that are appropriate to be applied in the DCL model in Fiqh learning, and some are appropriate or following modifications. Such lecturer-centered points should be proportionally arranged even if they are not abandoned altogether. Including controlling the learning process, lecturers do not need to be too dominant because students must be able to develop themselves independently.

According to Peterson (1979), the advantage of direct instruction is that lecturers can pattern and articulate active learning objectives, evaluate student development, and direct student assignments. Teaching facts, rules, and action sequences are suitable if taught using direct instruction (direct instruction) strategies. Meanwhile, teaching concepts, patterns, and abstractions are more appropriate to be taught using indirect learning strategies (indirect instruction). If you want student learning outcomes in the form of the ability to solve problems, think critically, and work cooperatively, then direct instruction must be combined with indirect learning (Ruutmann \& Kipper, 2011).

Wright \& DuCette (1976) suggested that direct instruction is suitable for students who are not independent in learning (external locus of control) and not suitable for students who are independent (internal locus of control) in finding their own meaning in learning. In the view of Peterson \& Janicki (1979), students who are not yet independent are suitable in learning in large classes together with many student friends then they can only do assignments independently. A similar view is expressed by Peterson (1979), who emphasized that direct instruction benefits students who are still not independent and vice versa disadvantaged students who are independent and can even make them frustrated because learning is very controlled by the lecturer.

Based on the opinion of Arends (2008), direct instruction learning through 4 syntaxes; 1) initial presentation (presentation); 2) practice and practice (practice); 3) assessment and evaluation; and 4) Monitoring and feedback (monitoring and feedback). There are three main duties of lecturers in the direct instruction; which are: 1) setting goals; 2) carry out a task analysis; and 3) planning time and space. These three main elements strengthen the mastery of declarative knowledge and procedural knowledge (Arends, 2008). The lecturer's three main tasks must be structured in unique stages so that students can achieve procedural knowledge, namely knowing the systemic procedures for doing things according to the proper stages and mastering demonstrative declarative skills.

\subsection{Contextual Learning}

\subsubsection{Definition of Contextual Learning}

Contextual learning or commonly known as Contextual Teaching and Learning (CTL) is a student-centered learning approach (Johnson, 2008). In this student-centered learning, they will get a good learning experience if what is experienced is related to what they have previously had as an experience at school (Nurhadi et al., 2004). There is a relationship between students' learning experiences in the classroom with the context of students' lives in the classroom as well as their daily lives as individuals and their relationship with life as members of society.

Johnson (2008) defines CTL as a system in a learning approach that fosters the potential of students' intellect to be able to assemble certain patterns to create a unique meaning in learning. This learning system aims to encourage the brain to do more than just study events in a place. These are the bottom assumptions obtained during growth. According to 
the researchers, lecturers need to understand correctly the principles of learning CTL so that students can manage a learning pattern more effectively.

\subsubsection{Characteristics and Components of Contextual Learning}

Berns \& Erickson (2001) explain that the essence of contextual learning is when students are able to find meaningful relationships between abstract concepts and the context of students' daily lives. Meanwhile, Johnson (2008) stated that a contextual learning approach is a condition in which the brain looks for the meaning of a specific relationship with the learning environment. Hull \& Schultz (2001) assumed that students naturally seek meaning in context and seek beneficial relationships from the learning environment. Fouad \& Byars-Winston (2005) emphasized that with a contextual approach, students will experience a complex and diverse learning process, which goes far beyond just stimulus-response.

According to Johnson (2008), there are seven learning components that form the basis for implementing CTL in the classroom. The seven components consist of: 1) constructivism; 2) ask; 3) find; 4) the learning community; 5) modeling; 6) reflection; and 7) actual assessment. The seven main components must be arranged in a learning frame by the lecturer in the learning room. A unique relationship is created between the lecturer, students, teaching material, and learning objectives. This unique series of learning ultimately fosters students' ability to find real learning contexts where they can relate learning outcomes to students' real-life contexts.

\subsection{Direct-Contextual Learning Model}

Modern Islamic University developed the DCL model development in Fiqh learning based on a needs assessment. The needs analysis is based on gaps from what is and should be there. The gap occurs because there is an imbalance between students' competence in the expected Fiqh subject and the learning conditions, which include learning conditions, learning methods, and forms of assessment of student learning outcomes. With the development of the DCL model, it is hoped that these learning problems can be overcome.

The DCL model is based on the idea of combining the principles of direct instruction (direct instruction) and contextual learning approaches (contextual teaching and learning). The DCL model's uniqueness lies in the subject of learning, where direct instruction is more lecturer-centered while the student-centered contextual learning approach. The characteristics of each direct instruction and contextual learning are considered capable of being a solution in solving existing problems.

As a learning model, DCL has unique characteristics because it was developed based on contextual learning approaches and direct instruction. CTL learning encourages students to be able to find their meaning of learning and be able to link learning outcomes with a more concrete life context. In contrast with direct instruction, the lecturer's role is undeniable in learning. The central role of lecturers in direct instruction is to guide students during the learning process.

The relevance of combining the two direct instruction and contextual models lies in regulating the balance of lecturer roles and student participation. The harmony of the DCL model, which combines the concepts of direct and contextual learning, lies in how this learning model provides flexibility to students in discovering the meaning of learning for themselves. However, on the other hand, it still provides a place for lecturers to guide students to find procedural skills in meaningful learning. 


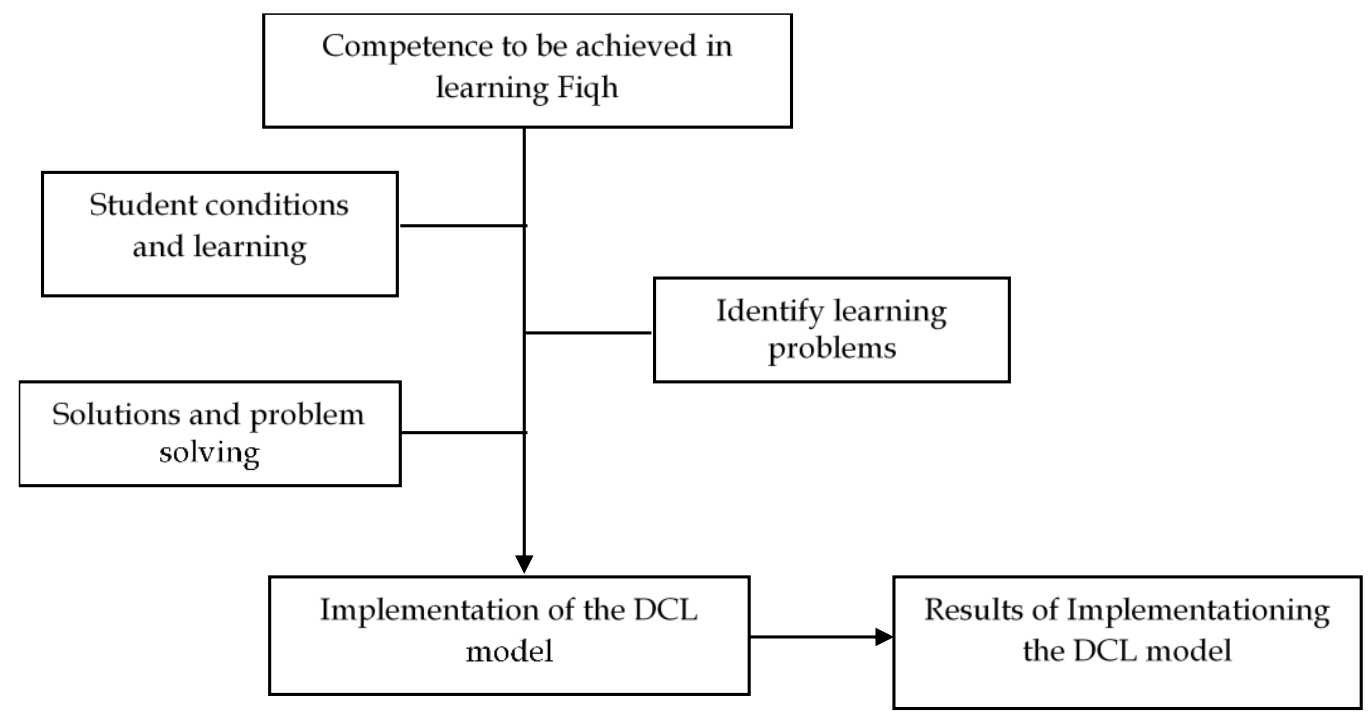

Figure 1. Basic DCL Model Development

\subsection{The Suitability of the DCL Model in Fiqh Learning}

The DCL model offers a balanced pattern of lecturer dominance in the entire learning process. In principle, the lecturer becomes a facilitator, not a dictator in the learning space (LaMasfer et al., 1998). In the DCL model development, the lecturer's role must still be in the initial and final activities of learning. In the early learning activities, the lecturer sets the direction and objectives of Fiqh learning in This is essential because the Fiqh material relates to various other disciplines such as Ushul Fiqh, Ulumul Qur'an, Ulumul Hadith, Balaghah, and other Arabic language disciplines. Conclusions of developing opinions and development of the context of Fiqh law in real life in the comparative Fiqh studies that are studied. In this stage, the lecturer's role is vital to assist students in the correct methodology and legal istimbath (conclusion). In this DCL model, pure lecturer plays a role in facilitating students to become active and independent in studying.

The DCL model makes use of active learning methods. The lecture method is not a problem because each method is unique and suitable for certain learning materials. Still, if the learning method is used too often and takes too much of the learning portion, it will cause student passiveness. Through inquiry in the CTL learning approach, students are expected to analyze and find facts on learning resources and develop them (Hwang et al., 2015). The Fiqh study problem needs reasoning if it leads to different legal rulings in other conditions and contexts. Through the inquiry method, students are expected to discover new facts in the learning process.

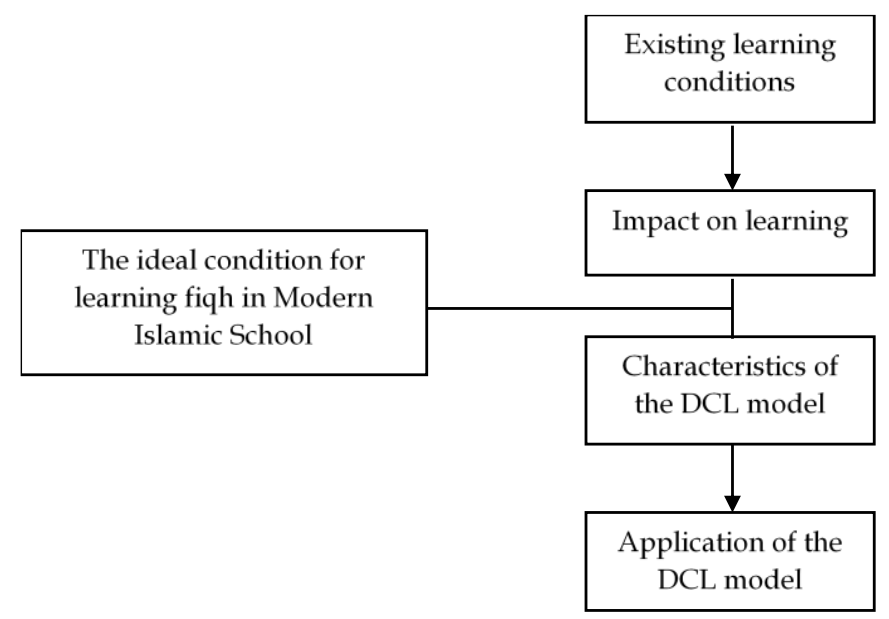

Figure 2. DCL Model Thinking Flow in Islamic Fiqh Learning 
In addition to the inquiry, the DCL model also suggests discussion and question and answer methods. With the development of discussion and questions and answers, the learning atmosphere will be conditioned to be active. There will be a dynamic exchange of knowledge and experiences between students through question and answer; students can learn from anything and with anyone (LaMasfer et al., 1998). At this stage, the lecturer becomes a learning facilitator, guiding students in studies and new findings, becoming a discussion partner, and asking questions if there are things beyond the reach of students' knowledge.

\section{Method}

\subsection{Research Design}

This research applied research and development $(\mathrm{R} \& \mathrm{D})$ method with a systematic approach using a development procedure adapted from (Dick et al., 2001), which is divided into four stages of R\&D, namely: (1) The research phase consisted of a preliminary study, a literature review, and an analysis of student learning difficulties. At this stage, an assessment of needs was conducted to determine the urgency of developing teaching materials; (2) The development phase consisted of several steps, namely, prototype design, prototype development, and prototype implementation; (3) In the design stage, storyboards were made to represent teaching materials and then developed through the addition of some content using the syntactic DCL model; (4) The next stage was the quality and feasibility test by experts and students to determine the quality of the DCL model in Fiqh learning and their effectiveness is based on the ability to reduce the difficulty of Fiqh learning, as demonstrated by the increase in posttest scores.

\subsection{Research Participants}

The research participants are 100 first-year undergraduate students at Gontor Islamic University who have not received comparative fiqh material at the tertiary level. The purposive sampling technique was applied to determine the target participants.

\subsection{Instrument and Data Collecting Technique}

The instruments used in this study were the DCL questionnaire and tested the learning outcomes of Islamic Civilization History. DCL questionnaire contains expert judgment and columns to provide revisions related to the DCL model and Lesson Planning DCL developed. The learning outcome test consisted of 10 descriptive questions with the category of analysis on comparative Fiqh of schools adapted from the book Bidayatul Mujtahid (Ibnu Rusyd, 1988), to assess the effectiveness of the DCL application model. Bidayatul Mujtahid is a fiqh book that discusses the comparative Fiqh of schools of thought. This book by Ibn Rushd is considered the best book in explaining the causes of differences of opinion among the scholars on every fiqh issue. The result of the validity test using the Pearson product-moment correlation after the prototype implementation phase is 0.0003 . This indicated that the learning outcome test is a valid and feasible instrument to use.

Data collection was carried out through questionnaires, literature study, and learning outcomes tests. Questionnaires and learning outcomes tests were collected at the final development stage, namely the quality and feasibility test. The questionnaire was taken from the experts' results and learning outcomes after applying the DCL model. The questionnaire has been compiled and then shown to the supervisor for revision (Dick et al., 2001). Furthermore, to test the validity, the questionnaire was tested by distributing questionnaires to two Expert validations, which have carried out the feasibility and material program. The questions that pass the validity test were then compiled into the questionnaire used in the study, then distributed to the experts. The data collected from the questionnaire were processed, presented, and analyzed. A literature review was conducted by reviewing international journals related to the DCL model to provide basic and sufficient insights concerning the implementation of its programs on colleges throughout the world before conducting further research on the evaluation of the DCL program in the Modern Islamic University.

\subsection{Data Analysis Techniques}

The questionnaire data were analyzed based on a rating scale and expert validation assessment criteria. The assessment scale uses a Likert scale consisting of 4 score is very valid, 3 score is valid, 3 score is less valid, and score 1 is invalid. The assessment criteria (A) consist of $3.6 \leq$ (A) $<4$ is without revision, $2.6 \leq$ (A) $\leq 3.5$ is a minor revision, $1.6 \leq$ (A) $\leq 2.5$ is a multiple revision, and $1 \leq$ (A) 1.5 is not proper to use.assessment scale uses a Likert scale consisting of 4 score is very valid, 3 score is valid, 3 score is less valid, and score 1 is invalid. The assessment criteria (A) consist of $3.6 \leq(\mathrm{A})<4$ is without revision, $2.6 \leq(\mathrm{A}) \leq 3.5$ is a minor revision, $1.6 \leq(\mathrm{A}) \leq 2.5$ is a multiple revision, and $1 \leq(\mathrm{A})$ 1.5 is not proper to use.

Data on the learning outcomes results were tested by statistic descriptive, Mann-Whitney test, and two-sample t-tests 
from the experimental class and the control class. In this research, the practical class got the implementation of DCL, while the control class got the implementation of non-DCL (indirect teaching). Nazir (2011) stated that the data must be tested for normality before being subjected to a t-test. However, if the data are not normally distributed, the t-test is replaced with the u-Mann-Whitney test. All tests were carried out using the SPSS 18 program. The basis for the decision of the two-sample t-test and the Mann-Whitney test was based on significance values comparing the calculated values and the table values. If the significance value (Sig). < probability 0.05 , then there is an influence between two variables. If the significance value ( $\mathrm{Sig}$ ). > probability 0.05 , then there is no influence between the two variables. Then, at the end of the stage, the experiment class was compared with the non-experimental class, in which the analysis was performed using two-sample t-tests. The purpose of the comparison is to determine the effectiveness of the DCL model.

\section{Results}

\subsection{Direct-contextual Learning Model Design}

The DCL model was developed based on the idea of how to create an appropriate learning model for comparative Fiqh subjects in Bidayatul Mujtahid (Ibnu Rusyd, 1988) as teaching material in Gontor Islamic University. The DCL model syntax development result is shown in Table 1.

Table 1. The Learning Syntax of the DCL Model in Fiqh Subject

Phase

\section{Lecturer}

\section{Description}

\begin{tabular}{ll}
\hline Introduction & $\begin{array}{l}\text { The lecturer makes an apperception and } \\
\text { relates previous student experiences related } \\
\text { to learning objectives. }\end{array}$ \\
Presentation & $\begin{array}{l}\text { The lecturer introduces concepts that need } \\
\text { to understand in learning new material and }\end{array}$ \\
& then demonstrates procedures, scope, \\
& mapping problems in the study, and ways of \\
& Istidlal (ratiocination).
\end{tabular}

Context The lecturer directs student activities on the Exploration subject's theme that students will study to fit the learning objectives, and then the lecturer plays himself as a learning facilitator.

Confirmation The lecturer guides students to reflect on the
learning outcomes and align the
implementation of Istidlal methods and
conclusions if deemed inappropriate.

Closing Lecturers conduct evaluations that lead to the achievement of learning objectives in authentic assessment and extended practice.

\section{Students perform prior learning experiences} related to learning objectives.

Students pay close attention to the lecturer's presentation in a modeling process.

Independently or in collaboration, students explore learning resources in the inquiry learning approach and questions and answers between students or lecturers with learning outcomes in the form of procedural-declarative knowledge and the ability to link learning outcomes to reallife contexts.

Students make a summary, reflection, and demonstration of the study results in the form of procedural-declarative knowledge and students' ability to link learning outcomes with real-life contexts in the subject of Fiqh.

Students celebrate success by performing learning outcomes in authentic assessment and extended practice.

Table 1 shows that the DCL model consists of five phases: introduction, presentation, context exploration, confirmation, and closing. The context exploration phase is implementing the contextual learning approach, and confirmation is implementing the DCL model. Each phase shows the integration of Fiqh learning materials where students explore learning resources by taking the proposition or Istidlal. The DCL model's design is based on the principle of innovation in the learning process of Fiqh material in Modern Islamic University. These innovations can certainly offer a new thing in advanced Fiqh, i.e., students' role in the learning process and learning outcomes. In addition to student involvement, students' independence in exploring teaching materials is also the focus of new designs on Fiqh in Modern 
Islamic University, which so far has been dominated by the role of lecturers. This innovation principle was conveyed by Ely (1999) when developing the learning process. Innovation in the learning process with the principle of solving learning problems will lead to maximum learning outcomes because maximum learning results are obtained from the correct learning process.

\subsection{The Implementation of DCL Model}

The benefits DCL model can be observed from the achievement of learning outcomes in the form of proceduredeclarative knowledge and the ability to relate learning outcomes to the context of student life through discoveries and observations that are formulated in the unique syntax. The orientation on aspects of usefulness in the development of this model (Ely, 1999).

Table 2. Result of Expert Assessment

\begin{tabular}{lll}
\hline \multicolumn{1}{c}{ Aspect } & \multicolumn{1}{c}{ Indicator } & Score \\
\hline Goal & Learning models are designed to achieve specific learning goals & 4 \\
& The goal of learning to be achieved has a strong foundation & 4 \\
\multirow{3}{*}{ Syntax } & The designed learning model has a clear syntax & 4 \\
& Each of the designed syntax items has a strong theoretical foundation & 3 \\
& The order of syntax is logically arranged & 4 \\
Support system & The learning model has a supporting system component & 4 \\
& Supported systems have a robust theoretical basis & 3 \\
Reaction principle & The reaction principle composite component illustrated how lecturers should see & 4 \\
& and treat students, both individually and in groups, as well as in their entirety & \\
& The learning model has a reaction principle component & 4 \\
& & Mean
\end{tabular}

Table 2 shows the result of expert validation of syntax of direct-contextual in Fiqh Learning. The result of the expert assessment showed 3.8. It means that the DCL has the feasibility applied in learning.

Table 3. Recapitulation of Research Result Score Lesson Planning Fiqh

\begin{tabular}{cclccc}
\hline Score & Category & $\begin{array}{c}\text { Range score } \\
\text { planning learning }\end{array}$ & total & \% & $\begin{array}{c}\text { Mean each } \\
\text { category }\end{array}$ \\
\hline $86-100$ & A & $87.5-100$ & 71 & 78.88 & 92.50 \\
& & $72.5-85$ & 19 & 82.76 & 82.76 \\
& & Mean & & 90.44 \\
\hline
\end{tabular}

Based on the data in Table 3, the implementation of the DCL at Gontor Islamic University still needs some improvement and is categorized as good. It showed that DCL gave good alternative model teaching and learning.

Table 4. Mann-Whitney Test Result Posttest

\begin{tabular}{lc}
\hline \multicolumn{2}{c}{ Test Statistics } \\
& Fiqh Posttest Result \\
\hline Mann-Whitney U & 155.500 \\
Wilcoxon W & 651.500 \\
Z & -4.928 \\
Asymp. Sig. (2-tailed) & .000 \\
\multicolumn{2}{c}{ Grouping Variable: Class } \\
\hline
\end{tabular}

Table 4 shows that the DCL research in the study of Fiqh can be considered effective based on the Mann-Whitney test results, which showed the value of Sig. (2-tailed) of 0,000 and less than 0.05 , so there is a significant difference between the control class and the experimental class. Furthermore, the experimental class was shown to have higher 
achievement in learning outcomes than the control of student learning outcomes. Thus, it can be judged that the learning model developed can lead students to better learning outcomes.

Table 5. The Result of Two-Sample T-Test of Both Experiment and Non-Experiment Class

\begin{tabular}{lllll}
\hline & $\mathbf{N}$ & Mean & Std & SE Mean \\
\hline Experiment Class & 50 & 75.35 & 9.002 & 1.64 \\
Control Class & 50 & 53.92 & 14.495 & 2.64 \\
Estimate for different: 1.002 & & & & \\
95\% Cl for different: $48.7,72.1$ & & & \\
t-test of different: t-value= $=1.32, \mathrm{p}$-value= $=0.002, \mathrm{DF}=10$ & \\
Std dev $=2.3627$ & & &
\end{tabular}

In the results of the Two Samples T-Test output above, the value of $t=1.32$ and Sig. (2-tailed) or $p$-value $=0,002<0.05$ or Ho is rejected. Then, there is a significant difference in the posttest score, which is 53.92 for the control class and 73.35 for the experimental class. This shows that the increase in the experimental class was higher than the control class. Based on the findings and discussion above, the DCL model can be an alternative model to teach Fiqh in Modern Islamic University.

\section{Discussion}

This study's findings indicate that the DCL model can optimize student fiqh learning outcomes more logically and rationally. This is done by linking the basics of Islam through contextual critical analysis of people's lives in Modern Islamic University at the level of higher education. Anwar (2019) showed that Fiqh learning that links a life context can maximize the function of reason oriented towards students' logical and rational thinking to understand fiqh knowledge deeper. In the DCL model, research in the study of Fiqh can be effectively said based on the results of the Mann-Whitney test on the control class and the experimental class. Zarkasyi (2015) view the role of a lecturer in learning is still important because he is the leader of learning. Although there has been a change of learning paradigm that was originally centered on lecturers switching centered on the students (students center), it will not shift the role of lecturers. The result led to the same conclusion as the view of Rahman et al., (2017), which shows that learning is also done by applying several components in contextual learning and always contextualizing or connecting learning with everyday life, so students feel that the learning process is more meaningful.

This research shows that to achieve maximum learning outcomes in Fiqh learning, this requires synergy in fostering active contextualization learning. The features of the student learning environment become facilitators in the contextualization of active learning. Silseth \& Erstad (2018) show descriptions of lecturers' contextual learning using their knowledge of society as a starting point for their teaching. In the case of this study, students bring their authentic concerns and problems in their learning. When students are allowed to choose and work on their own topics, especially in general science such as this research, they provide support and feedback for each topic because they may not have the required knowledge base. Alternatively, this knowledge becomes too intensive for them to deal with, as is usually the case in open project-based science (Polman, 2012).

In addition, the integration of the DCL model gives rise to interactions between students and lecturers generated through interactive tasks or provides feedback in learning activities. These interactive assignments also systematize and summarize acquired knowledge, enhance skills, and facilitate students in applying material learned in practice contextually (Shcherbakova \& Ilina, 2019). Thus, the combination of direct instruction and contextual teachinglearning can contribute to student activities to draw conclusions, which in this case, the research is the proposition.

Implementing the DCL model is suitable for Fiqh learning in Modern Islamic University at the level of higher education with classical learning patterns. Classical learning is a form of student and lecturer learning in one classroom. The implementation of the DCL model is not suitable when applied to Fiqh at the level of higher education because learning in Modern Islamic University is generally carried out by means of sorogan, bandongan, and wetonan. The three terms mentioned in the previous sentence is a specific learning model in Modern Islamic University. The sorogan method's implementation, students faced the grand lecturers one by one by bringing the reference book he was going to study (Zarkasyi, 2015). Therefore, the implementation of the DCL model is suitable if it is less suitable when applied to Fiqh learning in general. However, this method is still possible to be applied to Modern Islamic University, which has classical learning patterns and similar teaching materials. Based on the discussion above, the developed DCL can be used for undergraduate-level students to understand Fiqh learning. The developed learning design can overcome the 
limitations of undergraduate level students in the material at higher education.

\section{Conclusion}

The development of Islamic education at Modern Islamic University demands a change in the teaching system in a contemporary direction. The main problem is the unavailability of learning models at Modern Islamic University in facilitating students in constructing comparative Fiqh knowledge more logically and rationally. In fact, students need support in conducting critical studies of the scholars' decisions and postulates from the Al-Qur'an and Al-Hadith related to studying the context of daily life scientifically. The result of this research is the availability of the DCL model and the DCL teaching plan in the Fiqh subject at the tertiary level, especially for Modern Islamic University. The DCL phases consist of an introduction, presentation, context exploration, confirmation, and closing. The expert's assessment results show that the DCL model is suitable for constructing comparative fiqh knowledge of students more logically and rationally. Based on the Mann-Whitney test and two-sample t-test, the DCL model effectively improves student fiqh learning outcomes. This is indicated by the significant difference in learning outcomes between the control class and the experimental class. Thus, the developed DCL model can be used as a new learning model, especially in Fiqh subjects. However, this model still has limitations in the lecturer's use and role as a facilitator and undergraduate level student assistant to gain knowledge contextually. Therefore, this requires a learning tool that must be developed by further research. The implication of the DCL model is to contribute to the availability of a learning model in the jurisprudence course at Modern Islamic University based on the construction of logical and rational thought through critical analysis of the opinions of scholars and postulates based on Islamic values and the context of people's daily life.

\section{References}

Amir, M. F., Mufarikhah, I. A., Wahyuni, A., Nasrun, \& Rudyanto, H. E. (2019). Developing 'Fort Defending' Game as a Learning Design for Mathematical Literacy Integrated to Primary School Curriculum in Indonesia. Elementary Education Online, 18(3), 1081-1092. https://doi.org/10.17051/ilkonline.2019.610145

Anwar, M. A. (2019). Management of Active Learning Strategies in Learning Fiqh in General Department Students. AL-HAYAT: Journal of Islamic Education, 3(2), 212. https://doi.org/10.35723/ajie.v3i2.62

Archer, A. L., \& Hughes, C. A. (2010). Explicit instruction: Effective and efficient teaching. Guilford Press.

Arends, R. I. (2008). Classroom Instruction and Management. McGraw-Hill.

Arifin, M. B. U. B., Nurdyansyah, Rindaningsih, I., \& Fauji, I. (2019). Teaching media of fiqh magazine model to improve prayer understanding in primary school students. Universal Journal of Educational Research, 7(8), 1820-1825. https://doi.org/10.13189/ujer.2019.070821

Berns, R. G., \& Erickson, P. M. (2001). Contextual teaching and learning: Preparing students for the new economy (Vol. 5). National Dissemination Center for Career and Technical Education.

Bloom, B. S. (1971). Handbook on Formative and Summative Evaluation of Student Learning. McGraw-Hill.

Dick, W., Carey, L., \& Carey, J. (2001). The systematic design of instruction . Nueva York, NY. Addison-Wesley, Longman.

Eickelman, D. F. (1974). Islam and the Impact of the French Colonial System in Morocco: A Study in Historical Anthropology. Humaniora Islamica, 2, 215-235.

Eickelman, D. F. (1978). The Art of Memory: Islamic Education and its Social Reproduction. Comparative Studies in Society and History, 20(4), 485-516. https://doi.org/10.1017/S0010417500012536

Ely, D. P. (1999). New Perspectives on the Implementation of Educational Technology Innovations (ED427775 ed.). the Educational Resources Information Center (ERIC).

Fouad, N. A., \& Byars-Winston, A. M. (2005). Cultural Context of Career Choice: Meta-Analysis of Race/Ethnicity Differences. The Career Development Quarterly, 53(3), 223-233. https://doi.org/10.1002/j.21610045.2005.tb00992.x

Hassan, A., Suhid, A., Abiddin, N. Z., Ismail, H., \& Hussin, H. (2010). The role of Islamic philosophy of education in aspiring holistic learning. Procedia - Social and Behavioral Sciences, 5, 2113-2118. https://doi.org/10.1016/j.sbspro.2010.07.423

Hull, G., \& Schultz, K. (2001). Literacy and Learning Out of School: A Review of Theory and Research. Review of Educational Research, 71(4), 575-611. https://doi.org/10.3102/00346543071004575 
Hwang, G.-J., Chiu, L.-Y., \& Chen, C.-H. (2015). A contextual game-based learning approach to improving students' inquiry-based learning performance in social studies courses. Computers \& Education, 81, 13-25. https://doi.org/10.1016/j.compedu.2014.09.006

Ibnu Rusyd, M. (1988). Bidayat al-Mujtahid wa Nihayat al-Muqtashid. Dar al-Qalam.

Johnson, E. B. (2008). Contextual Teaching and Learning. MLC.

Kemenag. (2020). Peraturan Menteri Agama Republik Indonesia Nomor 5 Tahun 2020. Menteri Agama Republik Indonesia Peraturan Menteri Kesehatan Republik Indonesia, Nomor, 65(879), 2004-2006.

Krathwohl, D. R., \& Anderson, L. W. (2010). Merlin C. Wittrock and the Revision of Bloom's Taxonomy. Educational Psychologist, 45(1), 64-65. https://doi.org/10.1080/00461520903433562

LaMasfer, K., Kinchin, G., Gall, K., \& Siedentop, D. (1998). Inclusion Practices of Effective Elementary Specialists. Adapted Physical Activity Quarterly, 15(1), 64-81. https://doi.org/10.1123/apaq.15.1.64

Nazir, M. (2011). Metode Penelitian (6 Edition). Ghalia Indonesia.

Noh, M. A. C., \& Huda, M. (2020). Understanding the Quran resources as main principles for family institution in islamic education. Journal of Critical Reviews, 7(2), 688-691. https://doi.org/10.31838/jcr.07.02.126

Nurhadi, Yasin, B., \& Senduk, A. G. (2004). Pembelajaran Kontekstual. Universitas Negeri Malang.

Nurtawab, E. (2019). The Decline of Traditional Learning Methods in Changing Indonesia: Trends of BandonganKitāb Readings in Pesantrens. Studia Islamika, 26(3). https://doi.org/https://doi.org/10.36712/sdi.v26i3.11026

Peterson, P. L. (1979). Direct Instruction: Effective for What and for Whom? Educational Leadership, 37(1), 46-48.

Peterson, P. L., \& Janicki, T. C. (1979). Individual characteristics and children's learning in large-group and smallgroup approaches. Journal of Educational Psychology, 71(5), 677-687. https://doi.org/10.1037/00220663.71.5.677

Polman, E. (2012). Effects of Self-Other Decision Making on Regulatory Focus and Choice Overload. Journal of Personality and Social Psychology, 102, 980-993. https://doi.org/http://dx.doi.org/10.1037/a0026966

Rahman, F. (1984). Islam and modernity: Transformation of an intellectual tradition (Vol. 15). University of Chicago Press.

Rahman, H., Thalib, S. B., \& Mahmud, A. (2017). Integrated Character Education in Social Sciences with Contextual Teaching and Learning Approach. The New Education Review, 48, 53-64. https://doi.org/10.15804/tner.2017.48.2.04

Rosenshine, B. (1995). Advances in Research on Instruction. The Journal of Educational Research, 88(5), 262-268. https://doi.org/10.1080/00220671.1995.9941309

Ruutmann, T., \& Kipper, H. (2011). Teaching strategies for direct and indirect instruction in teaching engineering. 2011 14th International Conference on Interactive Collaborative Learning, 107-114. https://doi.org/10.1109/ICL.2011.6059556

Rymarz, R. M. (2013). Direct instruction as a pedagogical tool in religious education. British Journal of Religious Education, 35(3), 326-341. https://doi.org/10.1080/01416200.2013.781992

Salavera, C., Usán, P., \& Teruel, P. (2019). Contextual problems, emotional intelligence and social skills in Secondary Education students. Gender differences. Annales Médico-Psychologiques, Revue Psychiatrique, 177(3), 223-230. https://doi.org/https://doi.org/10.1016/j.amp.2018.07.008

Shavit, U., \& Spengler, F. (2018). "There's Shari‘a , and there's Life": A Field Study on the Diffusion, Acceptance and Rejection of Fiqh al-Aqalliyyat al-Muslima at Reykjavik's Grand Mosque. Journal of Muslim Minority Affairs, 38(3), 338-359. https://doi.org/10.1080/13602004.2018.1524137

Shcherbakova, I. A., \& Ilina, M. S. (2019). Foreign Language Communicative Competence Formation of University Students by Using Interactive Teaching Methods. The New Education Review, 57, 173-183. https://doi.org/10.15804/tner.2019.57.3.14

Silseth, K., \& Erstad, O. (2018). Connecting to the outside: Cultural resources teachers use when contextualizing instruction. Learning Culture and Social Interaction, 17, 56-58. https://doi.org/10.1016/j.lcsi.2017.12.002

Tan, C. (1970). Educative Tradition and Islamic Schools in Indonesia. Journal of Arabic and Islamic Studies, 14, $47-$ 62. https://doi.org/10.5617/jais.4638 
Wang, H.-H., Charoenmuang, M., Knobloch, N. A., \& Tormoehlen, R. L. (2020). Defining interdisciplinary collaboration based on high school teachers' beliefs and practices of STEM integration using a complex designed system. International Journal of STEM Education, 7(1), 3. https://doi.org/10.1186/s40594-019-0201-4

Wen, S.-F., \& Katt, B. (2019). Learning Software Security in Context. Proceedings of the 14th International Conference on Availability, Reliability and Security - ARES '19, 1-10. https://doi.org/10.1145/3339252.3340336

Wright, R. J., \& DuCette, J. P. (1976). Locus of Control and Academic Achievement in Traditional and Non-Traditional Educational Settings.

Yunus, Y. (2018). Islam Dan Budaya (Nilai-Nilai Islam Dalam Proses Pernikahan Masyarakat Bugis). Titian: Jurnal Ilmu Humaniora, 2(1), 5-7. https://doi.org/10.22437/titian.v2i1.5217

Zarkasyi, H. F. (2015). Modern Pondok Pesantren: Maintaining Tradition in Modern System. TSAQAFAH, 11(2), 223. https://doi.org/10.21111/tsaqafah.v11i2.267

\section{Copyrights}

Copyright for this article is retained by the author(s), with first publication rights granted to the journal.

This is an open-access article distributed under the terms and conditions of the Creative Commons Attribution license (http://creativecommons.org/licenses/by/4.0/). 